\title{
STRATEGIA INFORMATYZACJI I ANALIZA PRZEDWDROŻENIOWA A CYKL ŻYCIA OPROGRAMOWANIA STANDARDOWEGO
}

\author{
Jędrzej Wieczorkowski \\ Instytut Informatyki i Gospodarki Cyfrowej \\ Szkoła Główna Handlowa w Warszawie
}

\begin{abstract}
Streszczenie: Publikacja przedstawia miejsce zajmowane przez strategię informatyzacji, analizę przedwdrożeniową i wybór rozwiązania w kontekście cyklu życia oprogramowania. Oparto się na przykładzie zintegrowanych systemów informatycznych zarządzania, które zazwyczaj występują jako pakiety standardowe adaptowane do potrzeb organizacji podczas ich wdrażania. Do przedstawienia problemu wykorzystano autorski dwusegmentowy model cyklu życia oprogramowania. Scharakteryzowano działania podejmowane w ramach powyższych faz.
\end{abstract}

Słowa kluczowe: strategia informatyzacji, analiza przedwdrożeniowa, cykl życia oprogramowania, oprogramowanie standardowe, systemy informatyczne zarządzania

DOI: $10.17512 /$ znpcz.2016.3.1.03

\section{Wprowadzenie}

W celu wyjaśnienia miejsca systemów informatycznych w przedsiębiorstwach często wykorzystuje się koncepcję cyklu życia oprogramowania. Podejście takie stosowane jest szeroko także w ekonomii i naukach o zarządzaniu. Powstają więc przykładowo modele cyklu życia: organizacji, produktu, technologii oraz informacji. Z punktu widzenia informatyki interesujące są rozważania na temat cyklu życia informacji. Zagadnienie to $\mathrm{w}$ perspektywie komputerowego wspomagania cyklu życia poruszył przykładowo D. Dziuba, który w podstawowej wersji zidentyfikował następujące fazy: tworzenia, przechowywania i dystrybucji, zarządzania, wyszukiwania, likwidowania informacji (Dziuba 2008).

Systemy informatyczne można traktować jako produkty. Możliwe więc byłoby zastosowanie ogólnego modelu cyklu życia produktu, wyróżniając przykładowo takie fazy, jak: badanie, wprowadzenie na rynek, wzrost, nasycenie (dojrzałość), spadek i wycofanie. W celu zawężenia ogólnego pojęcia produktu wskazane jest jednak przeprowadzanie analizy cyklu życia oprogramowania, a w szczególności systemu informatycznego zarządzania. Cykl życia systemu informatycznego obejmuje okres od zdefiniowania projektu, poprzez realizację, wdrożenie i utrzymanie systemu, aż do jego wycofania. W rozważaniach na ten temat warto wziąć pod uwagę specyfikę oprogramowania, polegającą na bardzo silnym powiązaniu go ze zmieniającą się technologią. Dodatkowo w przypadku systemów informatycznych zarządzania (SIZ) należy także brać pod uwagę ewolucję praktyki zarządzania organizacjami i zmienność wymogów stawianych przed systemami, wynikającą przykładowo ze zmienności prawa. 
Zagadnienie cyklu życia systemów informatycznych i informacyjnych jest szeroko poruszane w literaturze. Cykl życia systemu informatycznego można zdefiniować jako ciągły proces, wzorowany na cyklu życia organizmu, złożony z sekwencji wzajemnie spójnych, powiązanych ze sobą logicznie i logistycznie etapów umożliwiających stworzenie, wdrożenie i użytkowanie systemów informatycznych (Chmielarz 2000). Obejmuje okres od powstania u użytkownika potrzeby wprowadzenia systemu do wycofania systemu z eksploatacji. Określa on logiczną sekwencję działań, w jakiej rozwój systemu następuje i wskazuje kierunek przejścia z jednego działania do kolejnego (Pańkowska 2004). Jest procesem: inspiracji, tworzenia, utrzymania, rozwoju oraz schyłku lub reinkarnacji aplikacji osobliwie osadzonej w środowisku informatycznym organizacji (Olejniczak 2004).

Praktyczne zastosowanie analizy cyklu życia systemów informatycznych wymaga stworzenia odpowiedniego modelu. Według W. Chmielarza model cyklu życia to odwzorowanie procesu realnego postępowania w budowaniu systemu informacyjnego uwzględniające poszczególne fazy cyklu życia w postaci kanonicznej lub zmienionej przez istotne okoliczności zaburzające ten wzorzec (Chmielarz 2000). Problematyką cyklu życia systemów informatycznych zajmuje się głównie inżynieria oprogramowania. Zagadnienie to zostało również sformalizowane poprzez stworzenie norm, w szczególności ustanowionej w 1995 roku międzynarodowej normy ISO i IEC ISO/IEC 12207 „Software Life Cycle” (Information Technology - Software Life Cycle Processes, ISO/IEC-12207, 1995).

Modele cyklu życia w inżynierii oprogramowania zazwyczaj opierają się na podejściu liniowym lub ewolucyjnym. W literaturze tej dziedziny nauki można odnaleźć wiele szczegółowych propozycji modelu (por.: Pressman 2005; Sommerville 2003; Kobyliński 2005; Maciaszek, Liong 2004). W praktyce zazwyczaj łączy je podejście analogiczne do budowy obiektów materialnych od podstaw, a modele są przeznaczone głównie dla systemów dedykowanych. SIZ bardzo często natomiast opierają się na koncepcji oprogramowania standardowego (powielarnego), wykorzystując podobieństwo procesów biznesowych realizowanych w różnych organizacjach. Wymusza to w praktyce stosowanie odmiennego modelu cyklu życia dla tego typu systemów, uwzględniającego obok działań podejmowanych przez producenta oprogramowania także te podejmowane przez klienta.

Celem artykułu jest przeprowadzenie dyskusji, czy strategia informatyzacji oraz analiza przedwdrożeniowa powinny być traktowane jako fazy cyklu życia oprogramowania wspomagającego zarządzanie organizacjami, a także ewentualne osadzenie tych faz w autorskim modelu cyklu życia oprogramowania standardowego. Celem jest także opisanie typowych działań podejmowanych $\mathrm{w}$ ramach powyższych faz. Wykorzystano metodę poznania empirycznego, w szczególności obserwację uczestniczącą $w$ projektach opracowania strategicznych planów informatyzacji i w projektach wdrożeniowych, a także badania literaturowe oraz metody analizy, syntezy i modelowania. W kolejnych podrozdziałach zaprezentowano specyfikę cyklu życia oprogramowania standardowego, w szczególności klasy SIZ, zaproponowano model takiego cyklu oraz, w oparciu o niego, scharakteryzowano strategię informatyzacji i analizę przedwdrożeniową $\mathrm{z}$ wyborem systemu informatycznego. 


\section{Specyfika cyklu życia oprogramowania standardowego}

Klasyczne modele cyklu życia wywodzące się z inżynierii oprogramowania, jak wspomniano powyżej, przeznaczone są przede wszystkim dla tworzonych od podstaw całkowicie nowych systemów. Trzeba się zmierzyć z sytuacją, w której dąży się do jak najszerszego wykorzystywania elementów wcześniej istniejących. Na tym opiera się podejście komponentowe w modelu oprogramowania wielokrotnego użycia i w architekturze zorientowanej na usługi SOA (ang. Service-Oriented Architecture), a także do pewnego stopnia podejście obiektowe. Jednocześnie współczesne metodyki zarządzania projektami informatycznymi, jak chociażby metodyki zwinne, narzucają iteracyjne podejście do cyklu życia. Wszystko to prowadzi do opracowywania coraz bardziej złożonych modeli cyklu życia oprogramowania.

Analogiczna sytuacja, odnośnie wykorzystywania elementów wcześniej istniejących, występuje w przypadku SIZ. Z jednej strony dotyczy to wytwarzania tego typu oprogramowania przez producenta, $z$ drugiej - dotyczy także wykorzystywania elementów wcześniej istniejących podczas wdrażania oprogramowania. W efekcie w SIZ bardzo chętnie wykorzystuje się standardowe pakiety oprogramowania, które po dostosowaniu (kastomizacji) mogą być wykorzystywane w różnych organizacjach (przedsiębiorstwach, instytucjach). W zależności od specyfiki oprogramowania i organizacji złożoność procesu kastomizacji może być bardzo różna.

W konsekwencji na rynku istnieje duży wybór gotowych pakietów przeznaczonych do wykorzystania w różnorodnych przedsiębiorstwach. W literaturze inżynierii oprogramowania pakiety oferowane w postaci gotowych produktów komercyjnych można spotkać pod określeniem systemy klasy COTS (ang. Commercial Off The Shelf). Z punktu widzenia cyklu życia interesujące są rozważania Oberndorf, Brownsword i Sledge, które wyróżniły cztery obszary aktywności związane z oprogramowaniem klasy COTS, podzielone następnie na szczegółowe działania. Do podstawowych obszarów aktywności należą (Oberndorf, Brownsword, Sledge 2000):

- obszar inżynierii obejmujący kontekst, architekturę i projekt systemu, konstrukcję oprogramowania, zarządzanie konfiguracją, wdrożenie i wsparcie powdrożeniowe oraz ocenę projektu, a także badanie rozwiązań stosowanych na rynku;

- obszar biznesowy obejmujący szacowanie kosztów oprogramowania oraz relacje z odbiorcami i dostawcami, a także przyjęty model biznesowy;

- obszar kontraktowania obejmujący warunki umów, zasady nadzoru oraz negocjacje;

- obszar całości projektu obejmujący strategię biznesową, zarządzanie ryzykiem, udostępnianie informacji oraz uwarunkowania kulturowe.

W omawianym podejściu szczegółowe działania nie mają narzuconej kolejności, choć są wzajemnie powiązane. Odbywają się w sposób ciągły, stale się przeplatając.

Aby przedstawić w uproszczony sposób cykl życia typowy dla oprogramowania standardowego obejmujący przynajmniej większość z powyższych obszarów, autor niniejszego artykułu wykorzystuje własny model oparty na podejściu liniowym. 
Wyróżniono w nim dwa segmenty: (I) producenta - w tym segmencie w szczególności następuje wytworzenie oprogramowania - oraz (II) klienta w tym segmencie w szczególności następuje jego wdrożenie (por.: Wieczorkowski 2011, s. 99-108). Segment I jest w podstawowym przebiegu realizowany jednokrotnie, natomiast segment II wielokrotnie, niezależnie u każdego klienta. Segment I można opcjonalnie zmodyfikować, stosując przykładowo podejście iteracyjne wytwarzania oprogramowania, lecz zrezygnowano z tego zabiegu w celu utrzymania większej czytelności modelu. Natomiast w segmencie II podejście liniowe wydaje się zdecydowanie najtrafniejsze. Jednakże należy zauważyć, iż w obu segmentach mogą występować pewne iteracje związane przykładowo z opracowywaniem (segment I) i wdrażaniem (segment II) nowych wersji systemu lub wdrażaniem kolejnych modułów systemu (segment II).

Model ma za zadanie przestawiać w sposób uogólniony istniejącą praktykę wytwarzania i wdrażania standardowych pakietów SIZ. Został on w wersji uproszczonej przedstawiony na Rysunku 1.

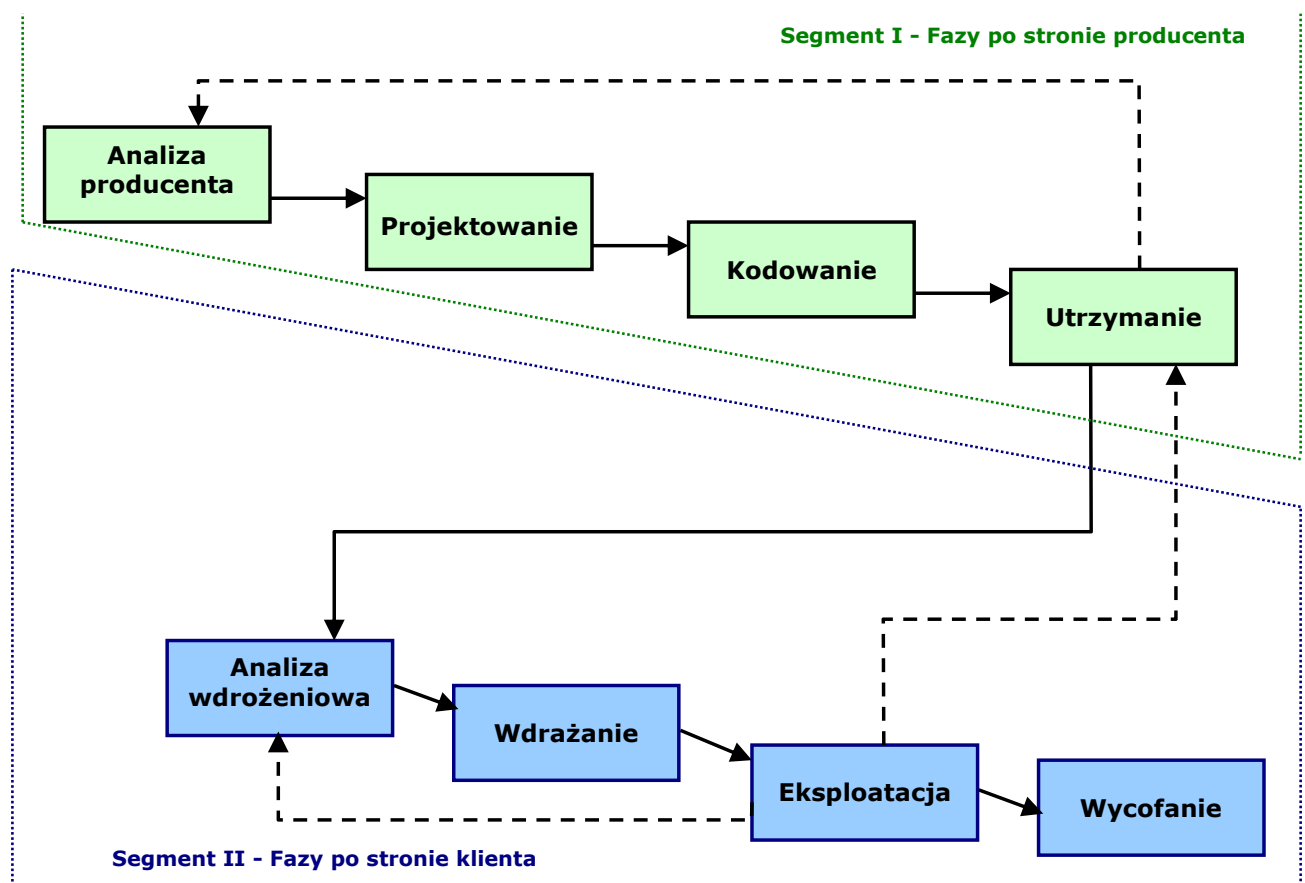

Rysunek 1. Uproszczony dwusegmentowy model cyklu życia oprogramowania standardowego

Źródło: Opracowanie własne

Podstawową wątpliwością jest powiązanie powyższego modelu z działaniami klienta mającymi na celu podjęcie decyzji o wyborze konkretnego pakietu programistycznego, których to czynności nie uwzględniono w uproszczonej wersji modelu. 
Przy poważnych inwestycjach informatycznych, np. w zintegrowane systemy klasy ERP (ang. Enterprise Resource Planning), decyzja powinna wynikać z opracowanej wcześniej strategii informatyzacji oraz dokonanego porównania rozwiązań dostępnych na rynku.

Czy powyższe argumenty uzasadniają umieszczenie tych działań w modelu cyklu życia oprogramowania? Przeciw temu, czyli za pominięciem strategii informatyzacji w cyklu życia, można wysunąć dwa podstawowe argumenty:

- Strategię informatyzacji można traktować jako część zarządzania strategicznego organizacją, nie zaś element wytwarzania oprogramowania.

- Strategia informatyzacji jest wstępem do całej informatyzacji organizacji, w tym wielu realizowanych projektów, a nie do pozyskania konkretnego systemu.

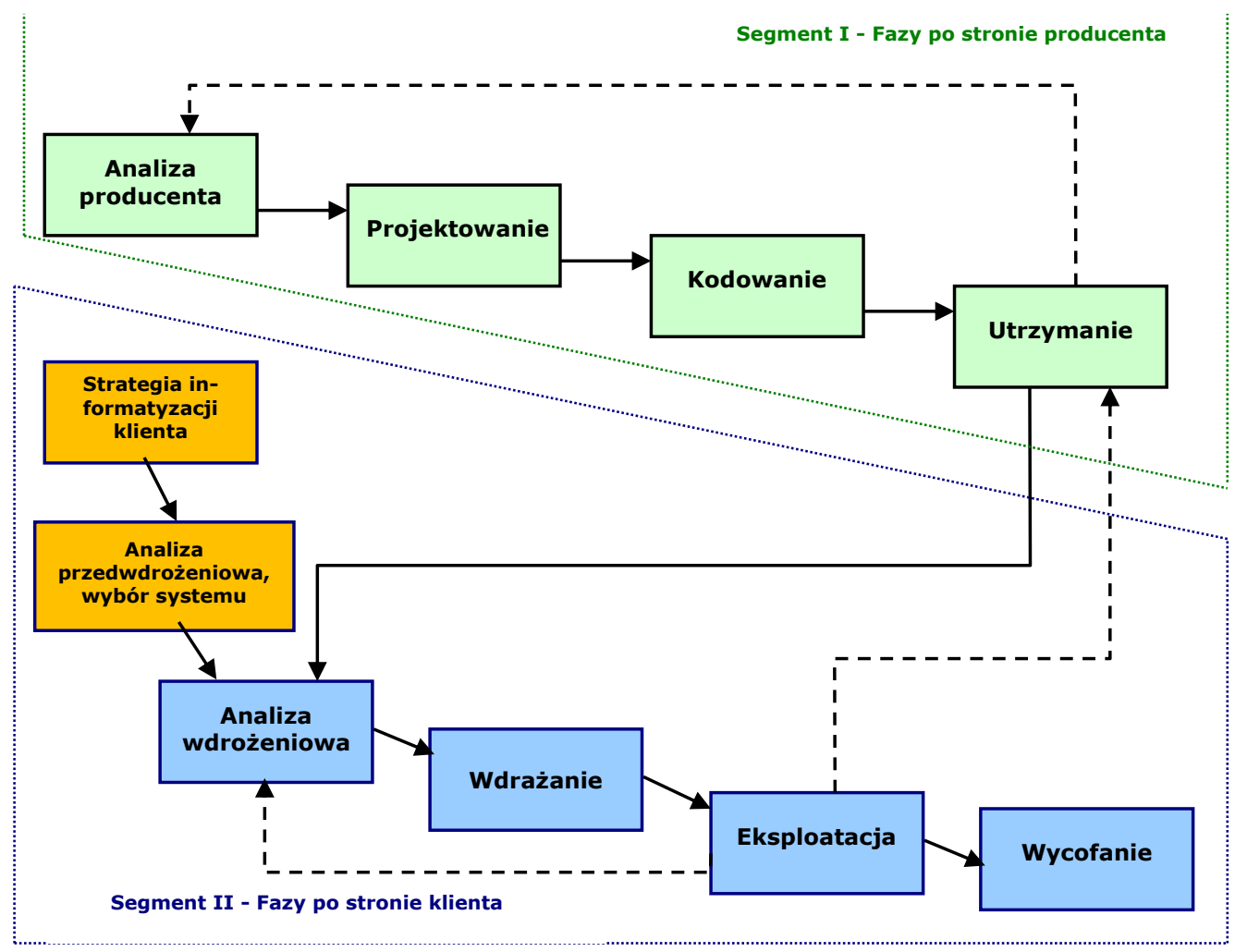

\section{Rysunek 2. Rozszerzony dwusegmentowy model cyklu życia oprogramowania standardowego}

Źródło: Opracowanie własne

Tym niemniej, jak wcześniej zaznaczono, szczególnie w przypadku planu pozyskania zintegrowanego systemu informatycznego zarządzania, faza strategiczna jest niezmiernie istotna. W praktyce decyduje ona nie tylko o fakcie podjęcia decyzji 
o rozpoczęciu projektu, lecz również o jego podstawowych założeniach. W konsekwencji, ze względu na swoją wagę, strategia informatyzacji została ujęta w zaproponowanym rozszerzonym modelu cyklu życia oprogramowania standardowego - jako pierwsza faza $\mathrm{w}$ segmencie klienta (II). Podobnie postąpiono z kolejną fazą, łącząc w niej analizę przedwdrożeniową i wybór systemu informatycznego. Rozszerzony model przedstawiono na Rysunku 2.

\section{Faza opracowania strategii informatyzacji klienta}

Opracowanie strategii informatyzacji jest więc pierwszą fazą realizowaną w segmencie klienta (II). Działania te wchodzą w zakres przygotowania strategii całej organizacji, rozumianej jako określenie podstawowych długofalowych celów przedsiębiorstwa oraz przyjęcie takich kierunków działania i takiej alokacji zasobów, jakie są niezbędne dla osiągnięcia tych celów (Chandler 1990). Strategia informatyzacji jest wynikiem podziału całościowej strategii organizacji w sposób hierarchiczny (strukturalny) na strategię biznesową oraz cząstkowe strategie funkcjonalne, które obejmują określone fragmenty działalności organizacji. Strategie funkcjonalne wydziela się zgodnie $\mathrm{z}$ podziałem pracy $\mathrm{w}$ organizacji, dotyczy to również wchodzących w skład strategii informatyzacji zagadnień IT.

Opracowanie strategii informatyzacji ma na celu zaplanowanie programu zastosowań technologii informacyjnych $\mathrm{w}$ organizacji. W ramach takiego programu może zostać zaplanowany cały portfel projektów IT. Podczas opracowywania planu strategicznego przeprowadza się m.in. analizę: zagrożeń działalności i niewykorzystywanych szans, planów rozwoju organizacji oraz ich powiązań z systemem informacyjnym. Identyfikuje się stan obecny systemu informacyjnego oraz cele i perspektywy zastosowań technologii informatycznych w przyszłości. W praktyce opracowanie strategii informatyzacji wymaga wcześniejszego sformalizowania ogólnej strategii biznesowej przedsiębiorstwa.

Przed opracowaniem strategii informatyzacji przedsiębiorstwo $\mathrm{w}$ zasadzie nie powinno jeszcze mieć podjętej decyzji o wyborze konkretnych systemów, choć w praktyce decyzja taka może być w pewien sposób narzucona, przykładowo gdy podmiot wchodzi w skład grupy kapitałowej, która ma opracowane swoje korporacyjne standardy informatyzacji. W przypadku gdy przedsiębiorstwo planuje wdrożenie zintegrowanego systemu informatycznego zarządzania, strategia informatyzacji ma specyficzny charakter ze względu na fakt, że dobór systemu jest decyzją niezwykle istotną. Na etapie określenia strategii informatyzacji wybór oprogramowania jest zazwyczaj dokonywany jedynie w zakresie ogólnych wymagań stawianych przed takim systemem. W niektórych przypadkach możliwe jest wskazanie konkretnego rozwiązania, lecz wtedy można mówić o scaleniu dwóch faz - strategii informatyzacji oraz analizy przedwdrożeniowej i wyboru systemu.

Można się spotkać także z poglądem, w którym ogół działań związanych ze zdefiniowaniem całościowej strategii (w tym biznesowej) zaliczany jest do fazy strategii informatyzacji, a nawet do szeroko rozumianej fazy analizy przedwdrożeniowej związanej z pozyskaniem systemu zintegrowanego. Przykładowo P. Lech w ramach 
przedwdrożeniowych prac dla takich systemów wyróżnił następujące kroki zaliczające się do opracowania strategii biznesowej przedsiębiorstwa (Lech 2003):

- ustalenie misji oraz celów gospodarczych organizacji,

- opis struktury organizacyjnej przedsiębiorstwa,

- określenie krytycznych procesów gospodarczych.

Zaliczenie działań związanych ze strategią biznesową do cyklu życia systemu jest jednak bardzo kontrowersyjne, ponieważ każda organizacja powinna posiadać aktualizowany dokument strategii biznesowej, pełniący faktycznie rolę nadrzędną wobec wszelkich, nie tylko informatycznych projektów. Ponadto wskazane wydaje się rozdzielenie opracowywania strategii informatyzacji, która może być wstępem do wielu przedsięwzięć IT, od analizy przedwdrożeniowej związanej z konkretnym zarekomendowanym do realizacji projektem.

\section{Analiza przedwdrożeniowa i wybór systemu}

Faza ta ma na celu doprecyzowanie wymagań stawianych przed zaplanowanym do wdrożenia systemem pod kątem jego właściwego wyboru oraz samo dokonanie wyboru oprogramowania i zawarcie kontraktu. Opracowywanie strategii informatyzacji ma w pewnym stopniu charakter analizy najwyższego poziomu, nie daje jednak odpowiedzi na wiele szczegółowych pytań, które często są niezbędne w procedurze wyboru systemu. Problem w szczególności dotyczy procedury zaku$\mathrm{pu}$, często przetargu na dostarczenie rozwiązań informatycznych. Zagadnienia organizacji przetargów są dość szczegółowo określone przez akty prawne i różnią się w zależności od formy prawnej i struktury własnościowej podmiotu. Szczególnym restrykcjom w Polsce, podobnie jak i w wielu innych państwach, podlegają m.in. administracja publiczna, spółki publiczne, a także projekty realizowane z wykorzystaniem środków publicznych. Przepisy narzucają sposób wyłonienia kontrahenta, w tym informacje, które muszą zostać udostępnione potencjalnym dostawcom. W Polsce ustawa Prawo zamówień publicznych zobowiązuje podmiotowo (według typów organizacji) i przedmiotowo (według typów zamówień) do stosowania narzuconych procedur postępowania (Ustawa z dnia 29 stycznia 2004 r.). Ma na celu racjonalizację gospodarowania środkami pieniężnymi. Niektóre wzorce wprowadzone w tej ustawie są w praktyce, przynajmniej w części, dobrowolnie stosowane również przez podmioty, których to prawo nie dotyczy.

W praktyce ogólne informacje o strategicznych potrzebach organizacji, wynikające $z$ dokumentu strategicznego planu informatyzacji, okazują się niewystarczające do zdefiniowania wymogów stawianych przed oprogramowaniem na potrzeby organizacji przetargu. Niezbędne jest wtedy przeprowadzenie dodatkowej analizy. Faza właściwej analizy wdrożeniowej po stronie klienta w prezentowanym modelu cyklu życia następuje dopiero po wyborze systemu i dostawcy. Z kolei w wyniku wcześniejszej analizy przedwdrożeniowej (określanej też jako „wstępna” lub „przetargowa”) powstaje opis wymagań na potrzeby wyboru systemu i ewentualnego przetargu. Dopiero w konsekwencji tej analizy, po zakończeniu procedury selekcji, następuje wybór systemu. Procedura wyboru jest silnie zależna od trybu 
zamówienia, jednak w ostatecznej ocenie ofert zawsze powinny być wzięte pod uwagę co najmniej takie czynniki, jak:

- funkcjonalność systemu wraz ze stosowaną technologią,

- koszt pozyskania i utrzymania systemu oraz warunki handlowe,

- ryzyko projektu wdrożeniowego, w tym wiarygodność i doświadczenie kontrahentów, realność harmonogramu i kosztorysu oraz stosowane metodyki zarządzania projektem.

Na tym etapie także określa się koncepcję wdrożenia, wybierając ewentualnego partnera do przedsięwzięcia. Wybór partnera może wynikać bezpośrednio $\mathrm{z}$ wyboru samego pakietu. Producenci lub dostawcy systemów zintegrowanych stosują różną politykę $\mathrm{w}$ zakresie procesu wdrażania. Niektórzy z nich sami we współpracy z klientem wykonują ten proces, inni zaś proponują partnerów wdrożeniowych. Może istnieć formalny wymóg producenta, aby partner wdrożeniowy posiadał stosowną autoryzację, choć często pozostawia się klientowi pełną swobodę doboru partnera, ponieważ odpowiedzialność za udane wdrożenie systemu w praktyce i tak spada na samego klienta. Wybór partnera może być więc niezależny od wyboru systemu. Teoretycznie przedsiębiorstwo może przeprowadzać samodzielnie wszystkie fazy pozyskania systemu w segmencie klienta, lecz w praktyce, w przypadku zintegrowanych systemów, rzadko jednak posiada pracowników o odpowiednich kwalifikacjach. W większości sytuacji uzasadnione wydaje się zawarcie umowy z partnerem wdrożeniowym, wspierającym klienta doświadczonymi konsultantami oraz wypróbowaną metodyką.

M. Flasiński zaproponował następujące kroki w zakresie analizy przedwdrożeniowej (Flasiński 2006):

- konstrukcja modelu dziedziny problemu,

- analiza wymagań użytkownika i definicja wymagań funkcjonalnych,

- analiza infrastruktury informatycznej organizacji,

- wstępna definicja projektu wdrożeniowego.

Natomiast w zakresie wyboru rozwiązania informatycznego zaproponował:

- przygotowanie bazy potencjalnych dostawców rozwiązania,

- przygotowanie formularzy tworzących zapytanie ofertowe,

- rozesłanie i odbiór wypełnionych przez oferentów formularzy,

- analiza merytoryczna produktów i usług,

- negocjacje merytoryczne i handlowe.

Należy zaznaczyć, że szczegóły wyboru dostawcy i kontraktowania zależne są od ewentualnej konieczności zastosowania przepisów dotyczących zamówień publicznych.

W modelu zaproponowanym w artykule analiza przedwdrożeniowa jest podstawą do właściwego wyboru oprogramowania. W poradnikach i publikacjach pisanych przez przedstawicieli firm związanych z konkretnymi rozwiązaniami technologicznymi i usługami wdrożeniowymi analiza przedwdrożeniowa często rozumiana jest szerzej, obejmując wszystkie czynności dotyczące badania organizacji przed samym wdrożeniem systemu, w tym późniejszej fazy wyodrębnionej w modelu jako analiza wdrożeniowa. Podejście takie zdaniem autora jest związane z powierzeniem zlecenia analizy przedwdrożeniowej partnerowi, który będzie także uczestniczył w samym 
wdrożeniu i leży raczej w interesie tego partnera, a nie jego klienta. Ogranicza ono możliwość obiektywnego wyboru systemu i zdefiniowania celów projektu.

\section{Podsumowanie}

Strategia informatyzacji jest jedną z funkcjonalnych strategii organizacji. Choć stanowi ona wstęp do realizacji całego portfela projektów informatycznych, możliwe jest włączenie jej, jako wyodrębnionej fazy, do modelu cyklu życia oprogramowania. Szczególnie jest to uzasadnione w przypadku standardowych zintegrowanych systemów informatycznych zarządzania, np. klasy ERP. Ich wdrożenia są zazwyczaj bardzo złożonymi projektami, które maksymalnie starają się wykorzystywać rozwiązania istniejące wcześniej (np. standardowe pakiety) w celu zmniejszenia kosztów i redukcji czasu przedsięwzięcia. Dla takich projektów opracowanie strategii informatyzacji ma charakter analizy najwyższego poziomu. Jej doprecyzowanie dla pożądanego rozwiązania to analiza przedwdrożeniowa, która dopiero umożliwia wybór zarówno konkretnego systemu, jak i ewentualnego partnera wdrożeniowego. Wyjaśnienie tych zależności ułatwia zaproponowany autorski dwusegmentowy model cyklu życia oprogramowania standardowego. Wymienione działania zostały włączone do modelu jako jego fazy w segmencie klienta (II). Takie podejście jest rozszerzeniem typowego dla inżynierii oprogramowania spojrzenia na cykl życia oprogramowania.

Praktyczne zastosowanie powyższego podejścia i wyraźne rozdzielenie projektu opracowania strategii informatyzacji oraz projektu przeprowadzenia analizy przedwdrożeniowej zakończonej wyborem systemu, a dopiero w ramach dalszych działań dokonanie analizy wdrożeniowej ułatwia dobór rozwiązań najbardziej odpowiadających potrzebom organizacji.

\section{Literatura}

1. Chandler A.D. (1990), Strategy and Structure: Chapters in History of the American Enterprise, The MIT Press, Cambridge.

2. Chmielarz W. (2000), Zagadnienia analizy i projektowania informatycznych systemów wspomagajacych zarządzanie, Wydawnictwa Naukowe Wydziału Zarządzania Uniwersytetu Warszawskiego, Warszawa.

3. Dziuba D. (2008), Information Life Cycle and Its Computer Support, "Research Papers Wroclaw University of Economics", No. 1208.

4. Flasiński M. (2006), Zarządzanie projektami informatycznymi, Wydawnictwo Naukowe PWN, Warszawa.

5. Information Technology - Software Life Cycle Processes, ISO/IEC-12207, 1995.

6. Kobyliński A. (2005), Modele jakości produktów i procesów programowych, Oficyna Wydawnicza SGH, Warszawa.

7. Lech P. (2003), Zintegrowane systemy zarzadzania ERP/ERP II. Wykorzystanie w biznesie, wdrażanie, Difin, Warszawa.

8. Maciaszek L., Liong B.L. (2004), Practical Software Engineering: A Case-Study Approach, Addison Wesley, Boston. 
9. Oberndorf T., Brownsword L., Sledge C. (2000), An Activity Framework for COTS-Based Systems, Software Engineering Institute, Carnegie Mellon University, Pittsburgh, http://www.sei.cmu.edu/publications/documents/00.reports/00tr010.html (dostęp: 13.07.2016).

10. Olejniczak W. (2004), Zarządzanie cyklem życia systemów - ku systemom wiedzy, [w:] Abramowicz W., Nowicki A., Owoc M. (red.), Zarzadzanie wiedza w systemach korporacyjnych, Wydawnictwo Akademii Ekonomicznej we Wrocławiu, Wrocław.

11. Pańkowska M. (2004), Inżynieria zarządzania przedsięwzięciami informatycznymi, [w:] Porębska-Miąc T., Sroka H. (red.), Systemy Wspomagania Organizacji 2004, Wydawnictwo Akademii Ekonomicznej w Katowicach, Katowice.

12. Pressman R.S. (2005), Software Engineering: A Practitioner's Approach, McGraw-Hill, Boston.

13. Sommerville J. (2003), Inżynieria oprogramowania, Wydawnictwa Naukowo-Techniczne, Warszawa.

14. Ustawa z dnia 29 stycznia 2004 r. Prawo zamówień publicznych (Dz.U. 2004 nr 19 poz. 177).

15. Wieczorkowski J. (2011), Pełen cykl życia systemów powielarnych wspomagajacych zarządzanie, [w:] Górski J., Orłowski C. (red.), Integracja systemów informatycznych nowe wyzwania, Pomorskie Wydawnictwo Naukowo-Techniczne, Gdańsk.

\title{
IT STRATEGY AND PREIMPLEMENTATION ANALYSIS IN THE SOFTWARE LIFE CYCLE
}

\begin{abstract}
The article presents IT strategy, preimplementation analysis and information system selection in the context of the software life cycle. The problem is based on the example of integrated management information systems (MIS) and software packages adapted to the needs of organizations during an implementation. Author used original two-segment model of the software lifecycle. The paper describes mentioned above phases of the life cycle.
\end{abstract}

Keywords: IT strategy, pre-implementation analysis, software life cycle, MIS, software packages 